\title{
Research and Construction of Practice Course System of Internet of Things
}

\section{Zuliang Wang, Wenzhun Huang, Canshi Zhu and Yun Shi}

\author{
Information Engineering College, Xijing University, Shanxi Xian 710123
}

Keywords: Internet of Things; Practice Course System; Optimized and Innovated

\begin{abstract}
To enhance the ability of innovation and entrepreneurship, the practice system of networking engineering is researched. The construction of practice teaching platform, practice teaching mode, and comprehensive experiment development projects are explored to vigorously promote the competition as a starting point for networking engineering graduates' innovation and practice ability to meet the need for the high quality application of the networking industry. The practice curriculum system of multi knowledge integration, cross curricular knowledge integration, the integration of existing knowledge and the development of knowledge, the integration of curricular and extracurricular research are Optimized and innovated.
\end{abstract}

\section{Introduction}

As a strategic emerging professional networking industry, it has obvious advantages in the industry, and our school networking engineering major has been selected as the provincial first-class professional candidate professional. Networking engineering major of our school is based in Shaanxi, following with the networking industry development direction, servicing for the national industry strategic information technology, cultivating sound personality, solid foundation knowledge, strong professional practice ability that have innovation, senior engineering and technical personnel in sensor technology, communication technology, network technology, intelligent information processing technology and other things related to engineering engaged in technology development and management. Since the inception of the professional, around the goal of applied talents cultivation, continuously strengthen the construction of teachers, deepen the teaching reform, building the experimental teaching platform, innovating personnel training mode to adapt to the trend of the new generation of information technology, highlighting the training features of innovative and applied technical talents, and it has remarkable results. Application oriented undergraduate emphasizes the cultivation of practical ability, promoting the cultivation of practical ability to adapt to the need of knowledge economy. It is not only beneficial to the cultivation of the international competitiveness of application oriented college students, but also to the development of colleges and universities. In order to promote the cultivation of entrepreneurship of College innovative application technology, it is necessary to adjust the guiding ideology, reform of personnel training mode, strengthen the construction of teaching staff, pay attention to practical teaching, with particular attention to the innovation of practical activities, and form the corresponding teaching management system. The study is research on training students' practice ability based on the research and practice of network system engineering practice to promote the cultivation of Applied Talents Scheme to keep pace with the times, and make efforts to explore the training mode to cultivate students' innovative ability as the main target of talent. 


\section{The Industry, Regional Advantages and Service Orientation of the Internet of Things Major Under the "First Class"}

"First-class professional" not only consider school from the strategic needs of the industry and the corresponding knowledge system, but also select the service object from the local resources and needs of the industry. Active research on the Internet of things industry structure, talent structure in Shaanxi, and understand the characteristics and needs of the professional services. Considering the development of positioning from the local and industry characteristics to determine the level of professional training and specifications, and then determine the practice of building the system objectives. For the application type undergraduate only authorized service object, based on the industry and local development, make full use of their own advantages, can provide high quality services for the level of society and industry and cultivate talents of high specification.

\section{The Construction and Improvement of the Hardware Environment of the Practice System of Internet of Things}

The Internet of things is a strategic new professional, China began to approve some of the 211 college enrollment in 2011, our school of networking project started enrollment in 2013. The current networking engineering laboratory is building, just use this opportunity to play the advantage, on the high starting point and high standard basis, and matched with the cultivation of applied talents of high specification. Internet of things belongs to information engineering institute, The Key Laboratory of precision agriculture information monitoring and processing is based on the construction of networking and big data as the core technology platform. The key laboratory in addition to have the task of undertaking training school projects and high level talents, also provide engineering, comprehensive, exploration and innovation of scientific research platform for networking undergraduate students, as the exploration of practical teaching activities. Combination the Key Laboratory with "comprehensive Networking Laboratory", "RFID and sensor network laboratory and other professional laboratory of organic, so as to achieve complementary advantages and apply high solid hardware specifications engineering for the networking of training talents.

\section{The Research on the Practice Model and the Development of the Experimental Project of the Verification Based Experiment + the Independent Exploratory Innovation Experiment}

Research and explore the practical teaching activity carrier, including the research exploration and the innovation experiment in the curriculum experiment, the comprehensive curriculum design based on the project research, the student extracurricular study and the independent innovation project.

Strengthen the engineering of the project content, the comprehensive of knowledge application, the diversity of methods and the exploration of the practice process. Create independent topics planning functional indicators, the design process of independent design, independent software and hardware platform to work and the practice of teaching ideas and practical results show for students. To create a practical teaching environment which is based on the coordination of hardware conditions and software resources, the cooperation of resource platform and interactive channel, the coordination of open practice and quality supervision, the renewal of ideas and the promotion of technology. 


\section{Taking Competition as the Starting Point to Promote the Innovation, Entrepreneurship and Practical Ability of Internet of Things Engineering Graduates}

To encourage students to participate in academic competitions, with competition, entrepreneurship and innovation projects to support students. The "one wing" training mode is integrated into practice teaching competition to improve team collaboration ability and engineering practice skills of students through the contest, and make the personnel training to adapt to the needs of the development of the industry. The specialty of Internet of things is a very strong cross specialty, which has the characteristics of electronics, communication, and computer and so on. In recent years, a number of open and things related to major events including "Internet plus" and "setbest Cup" National University biological network contest, TI Cup National University biological network design contest, the national electronic design contest and a series of academic competition is held providing a good training opportunity for the students. It has a greater impact on continuously carrying out and supporting by professional networking in the country, and participate in a wide range of competitions, stimulate students' interest and potential, and it plays a major role in the cultivation of students' practical ability, innovation ability, entrepreneurial ability and team spirit. and supported by professional networking in the country has a greater impact, and participate in a wide range of competitions, stimulate students' interest and potential, in the cultivation of students' practical ability, innovation ability, entrepreneurial ability and team spirit plays a major role.

\section{Conclusions}

In the background of "The Belt and Road" and "Internet plus" era, the project based on the economic development of Shaanxi, according the changes the demand for talents of networking industry, a combination of inside and outside is got by the teaching system of practice teaching practice in class, the cultivation of students' autonomous learning, knowledge, practice, team cooperation, explore the basic capacity and quality innovation purpose. Let the students learn in practice, research and exploration, design innovation. Let the students learn in practice, research and exploration, design innovation. The cultivation of innovation ability is integrated into every link and each item of University Teaching. Gradually enhance practical skills and innovative awareness, and ultimately enhance the ability of innovation and entrepreneurship to really have the ability to start with the knowledge economy.

\section{Acknowledgements}

Project supported by teaching reform project of Xijing University(JGYB1641,JGGH1703).

\section{References}

[1] WEI Xing, YANG Xiaojin, KE Jie. Applied Talent Trainingin Major of Internet of Things [J]. JOURNAL OF QINZHOU UNIVERSITY.2017,32(1):60-63.

[2] QIN Chun-jie, CHEN Li, WANG Cheng. Engineering Practice Bas;ed Experimental Teaching System of Logistics

Engineering [J].Research and exploration in laboratory.2016, 35(1):182-184.

[3] Qin L, Shi K, Gan Z. CDIO-based Research and Practice of Practical Course System for the Specialty of Internet of Things[J]. Research in Higher Education of Engineering, 2013.

[4] Zhang X Q. Research on practical teaching system of internet of things engineering specialty based on CDIO in clouds[J]. Journal of Wuhan Polytechnic University, 2016. 
[5] Liu Y Y, Hui-Min D U, Zhang L G. Research and Practice on S-CDIO Engineering Education Mode for the Specialty of Integrated Circuit Design and Integrated System[J]. Research \& Exploration in Laboratory, 2016.

[6] Yang H D. Research and Practice of Teaching Reform of Wireless Network Technology Course for Internet of Things Specialty[J]. Applied Mechanics \& Materials, 2014, 599-601:2040-2043.

[7] XIAO De-qin, XIAO Lei, PAN Chun-hua, et al. Practice Teaching Reform of the Network Engineer Specialty under the IOT Era[J]. Research and Exploration in Laboratory, 2017.

[8] Xianling L U, Mao L. Teaching Reform of Computer Network in the IOT Era[J]. Journal of Wuxi Institute of Technology, 2014.

[9] Liu X. Research on Teaching Reform of Computer Network Course in Application-Oriented Institutes[C]// International Conference on Education, Management, Commerce and Society. 2015.

[10] Yan Z P. Research and Practice of Teaching Reform of the Professional Core Competencies-oriented Computer Network[J]. Career Horizon, 2013. 